\title{
Bursa Injury
}

National Cancer Institute

\section{Source}

National Cancer Institute. Bursa Injury. NCI Thesaurus. Code C35671.

Trauma to a bursa. 